\title{
BENTUK DAN MAKNA PADA PENAMAAN SELAMETAN MASYARAKAT JAWA: KAJIAN LINGUISTIK ANTROPOLOGI
}

\author{
Anita Zuhrotul Jannah \\ Universitas Negeri Surabaya, Indonesia \\ anitazuhratuljnh@gmail.com
}

\begin{abstract}
Culture is one of the identities of a community in each region, one of which is selametan. Selametan is a culture that is closely related to the Javanese community. The purpose of this research is to describe the form and meaning in naming selametan Javanese society. The research data were obtained using competent observational techniques. The method of data analysis uses descriptive qualitative. Methods of data analysis through data transcripts and data classification. Data analysis uses morphological and semantic theories. The form of data analysis is descriptive. The results showed the naming of selametan in Javanese society consisting of 19 selametan consisting of pre-birth to death. Then the naming of the form is analyzed using morphological theory and its meaning is analyzed using semantic theory. The results showed that in terms of naming selametan, many Javanese people were formed from numbers during pre-birth and death, while in life they were formed from activities to be carried out. Whereas in meaning, the naming has lexical and referential meaning.
\end{abstract}

Keywords: form; meaning; selametan; Javanese society

Abstrak: Budaya menjadi salah satu identitas sebuah masyarakat pada setiap daerah, salah satunya selametan. Selametan merupakan salah satu budaya yang lekat dengan masyarakat jawa. Tujuan penelitian ada adalah mendeskripsikan bentuk dan makna pada penamaan selametan masyarakat jawa. Data penelitian diperoleh menggunakan tekhnik simak libat cakap. Metode analisis data menggunakan deskriptif kualitatif. Metode analisis data melalui transkipsi data dan klasifikasi data. Analisis data menggunakan teori morfologi dan semantik. Bentuk analisis data berupa deskriptif. Hasil penelitian menunjukkan penamaan selametan pada masyarakat jawa yang terdiri dari 19 selametan yang terdiri dari masa prakelahiran sampai kematian. Kemudian penamaan selametan tersebut dianalisis bentuknya menggunakan teori morfologi dan dianalisis maknanya menggunakan teori semantik. Hasil penelitian menunjukkan bahwa secara bentuk, penamaan selametan masyarakat jawa banyak dibentuk dari bilangan pada masa prakelahiran dan kematian, sedangkan pada masa kehidupan dibentuk dari kegiatan yang akan dilakukan. Sedangkan secara makna, penamaan tersebut memiliki makna leksikal dan referensial.

Kata Kunci: bentuk; makna; selametan; masyarakat jawa

Permalink/DOI: http://dx.doi.org/10.15408/dialektika.v7i1.13722 


\section{Pendahuluan}

Bahasa merupakan sebuah simbol atas ekspresi manusia. Hal tersebut selaras dengan pendapat Bahasa adalah suatu sistem lambang berupa bunyi, bersifat arbitrer, digunakan oleh suatu masyarakat tutur untuk bekerja sama, berkomunikasi, dan mengidentifikasi diri. ${ }^{1}$ Bahasa adalah satu sistem, sama dengan sistem-sistem lain, yang sekaligus bersifat sistematis dan bersifat sistemis. ${ }^{2}$ Bahasa menjadi hal mendasar yang melambangkan manusia. Karena malalui bahasa, manusia menuangkan segala bentuk ide, gagasan, pikiran, rasa, maupun ekspresi. Salah satu hasil cipta manusia melalui bahasa adalah budaya. Budaya merupakan salah satu identitas dari masyarakat yang lahir dari pandangan hidup, kepercayaan, nilai, ataupun simbol yang diturunkan kepada setiap generasi. Di Indonesia, setiap suku bangsa memiliki budaya yang melekat pada tiap masyarakatnya. Salah satunya, budaya selametan.

Budaya selametan lekat dengan masyarakat jawa. Budaya tersebut sudah dilakukan sejak zaman hindu-budha. Namun, budaya tersebut masih dilaksanakan hingga saat ini, baik di desa ataupun di kota. Selametan merupakan salah satu budaya masyarakat jawa yang bertujuan untuk memperingati dan mensyukuri tahap-tahap kehidupan manusia mulai prakelahiran hingga kematian. Pada tahap prakelahiran dimulai dari masa dalam kandungan. Masyarakat jawa meyakini bahwa ketika seorang ibu sedang hamil, keselamatan sang bayi dan ibunya akan terbantu dengan doa-doa yang dipanjatkan kepada tuhan dalam bentuk selametan. Selain itu, selametan juga bentuk rasa syukur atas anugerah ataupun rejeki yang telah diberikan oleh tuhan. Di setiap selametan, memiliki penamaan yang berbeda-beda dari kehamilan hingga kematian. Penamaan tersebut tak lepas dari unsur lambang dan makna di setiap peringatan. Hal tersebut membuktikan bahwa bahasa tidak dapat lepas dari sebuah budaya, begitu pula budaya yang tidak dapat lepas dari bahasa.

Penelitian ini difokuskan pada apa saja bentuk penamaan dari selametan masyarakat jawa dan makna dari penamaan selametan masyarakat jawa. Bertujuan untuk mendeskripsikan bentuk dan makna dari setiap penamaan selametan dalam masyarakat jawa, khususnya Jawa Timur. Penelitian ini diharapkan dapat bermanfaat untuk menambah kajian dalam bidang linguistik dan budaya, serta dapat menambah wawasan masyarakat mengenai bahasa dan

${ }^{1}$ Abdul Chaer, Linguistik Umum, (Jakarta: Rineka Cipta, 2007), h. 1

${ }^{2}$ Abdul Chaer, Pengantar Semantik Bahasa Indonesia. (Jakarta: Rineka Cipta, 2009), h. 30 
budaya, khususnya pada selametan masyarakat jawa. Penelitian ini belum pernah dilakukan sebelumnya, namun terdapat beberapa penelitian mengenai toponimi, register, atau penamaan yang pernah dilakukan sebelumnya dengan kajian yang sama, yakni linguistik antropologi. Penelitian pertama yaitu tentang Penamaan Kampung di Kecamatan Bandung yang dilakukan pada tahun 2017 oleh Rifki Handayani, dengan objek penelitian nama-nama kampung di Kecamatan Bandung. Teori yang digunakan adalah teori morfologi dan repesentasi budaya. Penelitian kedua berjudul Nama-nama Makanan dalam Sesaji Selametan Daur Hidup Masyarakat Jawa Studi Kasus Etnolinguistik, yang terbit pada tahun 2017 oleh Imam Baehaqie. Objek penelitian tersebut adalah nama-nama makanan yang ada dalam selametan masyarakat jawa dan dianalisis menggunakan teori semantik dan semiotik. Penelitian ketiga berjudul Tradisi Suran Masyarakat Triaji: Kajian Antropologi Linguistik, yang dilakukan pada tahun 2017 oleh Nur Alfi. Objek kajian tersebut adalah tradisi suran yang dianalisis menggunakan teori semiotik. Dari tiga penelitian tersebut, objek yang dipakai berbeda dengan objek yang dipakai dalam penelitian ini, namun samasama penelitian tentang budaya jawa. Kajian dalam tiga penelitian tersebut sama dengan penelitian ini, yakni linguistic antropologi. Namun, dengan teori yang berbeda.

Pada penelitian ini, teori yang digunakan untuk mendeskripsikan bentuk dan makna dari selametan masyarakat jawa adalah teori Morfologi dan Semantik. Morfologi merupakan cabang ilmu linguistik yang mempelajari tentang susunan atau bagian-bagian kata secara gramatikal. ${ }^{3}$ Adapun semantik dapat diartikan sebagai ilmu tentang makna atau tentang arti, yaitu salah satu dari tiga tataran analisa bahasa: fonologi, gramatika, dan semantik. ${ }^{4}$ istilah makna merupakan kata-kata dan istilah yang membingungkan. Makna tersebut selalu menyatu pada tuturan kata maupun kalimat. ${ }^{5}$ Maka, morfologi sebagai menelaah susunan kata ataupun proses pembentukan kata. Pada proses tersebut, sebuah kata dapat berubah makna dan bentuknya. Hal tersebut terjadi pada proses morfologi. Proses morfologi tersebut terbagi menjadi tiga proses, yang pertama yaitu afiksasi. Afiksasi merupakan proses penambahan afiks pada sebuah kata dasar. Afiksasi dibagi menjadi lima yaitu prefiks (awalan), infiks (sisipan), dan sufiks (akhiran), konfiks, dan simulfiks. Kedua, proses reduplikasi. Reduplikasi merupakan proses pembentukan kata ulang. Ketiga, proses

\footnotetext{
${ }^{3}$ Mulyana. 2007. Morfologi Bahasa Jawa. Yogyakarta: Kanwa Publiser, h. 5

${ }^{4}$ Abdul Chaer, Pengantar Semantik Bahasa Indonesia. Jakarta : Rineka Cipta, 2002), h. 2

${ }^{5}$ Mansoer Pateda, Semantik Leksikal. (Jakarta : Rineka Cipta, 2001), h.79
} 
pemajemukan atau komposisi. Pemajemukan merupakan proses morfologi yang menggabungkan dua kata dasar menjadi satu kata utuh yang memiliki makna baru, lain dari kata dasar tersebut. Selain pada bentuk penamaan selametan masyarakat jawa, penelitian ini juga mendeskripsikan makna pada penamaan tersebut. teori yang digunakan adalah teori semantik. Semantik merupakan cabang ilmu linguistik yang mempelajari tentang makna. Leech membedakan adanya tujuh tipe makna, yaitu makna konseptual, makna konotatif, makna stilistika, makna afektif, makna reflektif, makna kolokatif, dan makna tematik. ${ }^{6}$

\section{Metode}

Penelitian ini bersifat kualitatif. Artinya, data dan hasil penelitian berupa deskripsi mengenai penamaan selametan masyarakat jawa. Bogdan dan Taylor (dalam Moleong) menjelaskan bahwa penelitian kualitatatif merupakan prosedur penelitian yang menghasilkan data deskriptif yang berupa kata-kata tertulis atau lisan dari orang-orang dan perilaku yang diamati. ${ }^{7}$ Dalam pendekatan ini, peneliti ingin menemukan makna-makna yang terkandung dalam pemakaian bentuk kebahasaan pada masyrakat tertentu. Sumber data penelitian ini adalah informan yang memahami sejarah, seluk-beluk, dan tata cara tentang selametan masyarakat jawa. Informan pertama tersebut bernama Markun, berusia 60 tahun, berasal dari Ponorogo. Bapak Markun adalah pemimpin acara-acara keagamaan di kampungnya. Informan kedua bernama bernama Bapak Matawin, berusia 71 tahun, berasal dari Surabaya. Bapak Matawin adalah pemimpin acara-acara keagamaan di Kampungnya dan sebagai juru kunci Sawunggaling. Kedua informan tersebut adalah masyarakat asli suku jawa yang masih mengadakan selametan dari masa prakelhiran hingga kematian.

Data penelitian ini diperoleh menggunakan metode simak dan wawancara. Menurut Mahsun menyatakan bahwa metode simak diterapkan dengan teknik simak libat cakap. Metode libat cakap dilaksanakan dengan cara wawancara secara langsung pada informan. ${ }^{8}$ teknik yang digunakan melalui teknik pancing, artinya peneliti melakukan wawancara dengan informan yang bersumber dari pancingan pertanyaan yang telah disiapkan. Metode analisis data menggunakan deskriptif kualitatif. data yang telah didapatkan, ditranskipsikan terlebih dahulu. Kemudian data tersebut diklasifikasikan. Dan tahap akhirnya

\footnotetext{
${ }^{6}$ Chaer, Abdul. 2009. Pengantar Semantik Bahasa Indonesia. Jakarta: Rineka Cipta, h. 59

${ }^{7}$ Lexy Moloeng, Metode Penelitian Kualitatif (Bandung: Remaja Rosdakarya), h.4

${ }^{8}$ Mahsun, Metodologi Penelitian Bahasa: Tahap Strategi, Metode dan Tekniknya, (Bandung: PT. Raja Grafindo Persada, 2005), h. 95
} 
adalah analisis data menggunakan teori morfologi dan semantik. Bentuk analisis data berupa deskriptif, yaitu mendeskripsikan penamaan selametan masyarakat jawa yang dianalisis menggunakan teori morfologi dan semantik.

\section{Pembahasan}

\section{Nama-nama Selametan Masyarakat Jawa}

Berdasarkan hasil pengumpulan data di tempat penelitian, diketahui nama-nama selametan mulai dari prakelahiran hingga kematian berjumlah 19 nama. Dari data tersebut, nama-nama selametan tersebut diklasifikasikan berdasar pada waktu selametan dan berdasar pada asal usul bentuk penamaan tersebut.

\section{Tabel. 1 Nama-nama Selametan}

\begin{tabular}{llll}
\hline No & \multicolumn{1}{c}{ Data } & \multicolumn{1}{c}{ Waktu } & \multicolumn{1}{c}{ Bentuk } \\
\hline 1. & Neloni & Prakelahiran & Bilangan \\
2. & Mitoni & Prakelahiran & Bilangan \\
3. & Brokohan & Kelahiran & Kegiatan \\
4. & Sepasaran & Kelahiran & Waktu \\
5. & Neloni & Kelahiran & Bilangan \\
6. & Mitoni & Kelahiran & Bilangan \\
7. & Tedak siten & Kelahiran & Waktu \\
8. & Nyetaun & Kelahiran & Kegiatan \\
9. & Selametan khitan & Anak-anak & Kegiatan \\
10. & Selametan midodaren & Pernikahan & Kegiatan \\
11. & Nduduk pondasi & Membangun rumah & Kegiatan \\
12. & Mungga molo & Membangun rumah & Kegiatan \\
13. & Nelung dino & Kematian & Bilangan \\
14. & Pitung dino & Kematian & Bilangan \\
15. & Patang puluh dino & Kematian & Bilangan \\
16. & Satus dino & Kematian & Bilangan \\
17. & Nyewu & Kematian & Bilangan \\
18. & Pendhak & Kematian & Waktu \\
19. & Pendhak 2 & Kematian & Waktu \\
\hline
\end{tabular}

Dari data tersebut, diketahui terdapat dua selametan yang diadakan ketika masa pra kelahiran, enam selametan pada masa kelahiran, satu selametan pada masa anak-anak, satu selametan ketika pernikahan, dua selametan ketika membangun rumah, dan tujuh selametan ketika masa kematian. Pada klasifikasi bentuk, diketahui terdapat sembilan bentuk penamaan yang berasal dari kata bilangan, empat bentuk penamaan yang berasal dari waktu selametan, dan enam 
bentuk penamaan yang berasal dari kegiatan yang dilakukan ketika selametan. Dari klasifikasi tersebut, penamaan selametan masyarakat jawa tersebut dianalisis berdasarkan proses morfologisnya serta berdasarkan makna yang terkandung di dalam penamaan selametan masyarakat jawa.

\section{Tabel 2. Analisis bentuk}

Leksikon

\section{Proses Morfologi}

\section{Neloni}

Mitoni

Brokohan

Sepasaran

Tedhak siten
Berasal dari kata telu yang mengalami perubahan bunyi atau morfofonemik. Dalam proses morfologi bahasa jawa, apabila huruf \{n\}diikuti dengan kata dasar yang berawalan $/ \mathrm{p} /, / \mathrm{m} /, / \mathrm{t} /, /$ th $/$, / $/ /, / \mathrm{k} /, / \mathrm{s} /, / \mathrm{c} /$, dan $/$ ny $/$ maka fonem tersebut luluh menjadi satu dengan [n]. Kemudian mengalami proses perubahan bunyi di akhir kata yakni akhiran / i /. Dalam proses morfologi bahasa jawa, [ i ] mempunyai dua bentuk, yaitu / i / dan / ni /. Bentuk / ni / dipakai apabila kata dasar yang mengikutinya diakhiri dengan huruf vokal. Maka, kata [telu] berubah menjadi [neloni].

Berasal dari kata pitu yang mengalami perubahan bunyi atau morfofonemik. Dalam proses morfologi bahasa jawa, apabila huruf kata dasar yang berawalan $/ \mathrm{p} / / / \mathrm{m} / / / \mathrm{b} / \mathrm{w} /$ maka fonem tersebut luluh dan berubah menjadi / m /. Kemudian mengalami proses perubahan bunyi di akhir kata yakni akhiran / i /. Dalam proses morfologi bahasa jawa, [i ] mempunyai dua bentuk, yaitu / i / dan / ni /. Bentuk / ni / dipakai apabila kata dasar yang mengikutinya diakhiri dengan huruf vokal. Maka, kata [pitu] berubah menjadi [mitoni].

Brokohan merupakan kata serapan dari bahasa arab, yaitu barokah yang memiliki makna meminta berkah. Kemudian mengalami proses adaptasi dalam bahasa jawa. Pemakai bahasa hanya mengambil makna kata asing itu, sedangkan ejaan atau penulisannya disesuaikan dengan ejaan bahasa jawa menjadi brokoh. Kata brokoh merupakan nomina, kemudian mengalami proses afiksasi pada akhiran -an menjadi brokohan dan meng perubahan kelas kata menjadi verba.

Sepasaran berasal dari kata sepasar yang merupakan perhitungan waktu jawa. Kemudian dalam bahasa jawa mengalami afiksasi /-an/ menjadi [sepasaran].

Tedhak siten terbentuk dari dua kata kata, tedak dan siten. Kata tedak bermakna injak, dan siten yang bermakna tanah. Kedua kata tersebut termasuk dalam bentuk polimorfemis, yakni terbentuk dari medan makna dan dua kelas kata yang berbeda. 
Leksikon

Proses Morfologi

Selametan

khitan (untuk

laki-laki)

Selametan
midodaren

Nduduk

pondasi

Munggah molo

Telung dinane

Pitung dinane

Patang puluh dinane
Selametan merupakan kata serapan dari bahasa arab yaitu salamah yang artinya selamat. Kemudian mengalami proses adaptasi dalam bahasa jawa. Pemakai bahasa hanya mengambil makna kata asing itu, sedangkan ejaan atau penulisannya disesuaikan dengan ejaan bahasa jawa. Slametan khitan terbentuk dari kata slametan dan khitan, sehingga termask dalam polimorfemis karena terbentuk dari dua kata yang memiliki medan makna yang berbeda.

Selamatan midodaren berasal dari kata midodari yang artinya bidadari, yang mendapat proses gramatikal. Bentuk/-en/ dipakai apabila kata dasar yang diberi imbuhan itu berakhir pada konsonan.

Nduduk Pondasi terbentuk dari dua kata kata, nduduk dan pondasi. Kata nduduk bermakna menggali, dan pondasi yang bermakna dasar bangunan. Kedua kata tersebut termasuk dalam bentuk polimorfemis, yakni terbentuk dari medan makna dan dua kelas kata yang berbeda.

Munggah molo terbentuk dari dua kata kata, munggah dan molo. Kata munggah bermakna naik, dan molo yang bermakna kudakuda. Kedua kata tersebut termasuk dalam bentuk polimorfemis, yakni terbentuk dari medan makna dan dua kelas kata yang berbeda.

Berasal dari kata telu. Dalam proses morfologi bahasa jawa, kata bilangan yang berubah bunyi menjadi kata benda, maka akan mengalami modifikasi dalam hal jumlahnya, tingkatannya, atau urutannya saja. Jika kata bilangan tersebut terletak di bagian depan, maka kata bilangan tersebut menggunakan partikel penghubung /ng/ dan /q/. Sehingga kata [telu] berubah menjadi [telung].

Berasal dari kata pitu. Dalam proses morfologi bahasa jawa, kata bilangan yang berubah bunyi menjadi kata benda, maka akan mengalami modifikasi dalam hal jumlahnya, tingkatannya, atau urutannya saja. Jika kata bilangan tersebut terletak di bagian depan, maka kata bilangan tersebut menggunakan partikel penghubung /ng/ dan /q/. Sehingga kata [pitu] berubah menjadi [pitung].

Berasal dari kata patang. Dalam proses morfologi bahasa jawa, kata bilangan yang berubah bunyi menjadi kata benda, maka akan mengalami modifikasi dalam hal jumlahnya, tingkatannya, atau urutannya saja. Jika kata bilangan tersebut terletak di bagian depan, maka kata bilangan tersebut menggunakan partikel penghubung /ng/ dan /q/. Sehingga kata [patang] berubah menjadi [patang]. 
Leksikon

Proses Morfologi

satus dinane

Dalam proses morfologi bahasa jawa, bilangan 100 memiliki proses yang berbeda, yaitu bahwa pada bilangan 100, antara sa + atus tak ada penghu-bung $=\mathrm{q}$, dan bahkan antara sa dan atus terjadi kontraksi.

Mendhak Mendhak bermakna selametan yang dilakukan setelah satu tahun kematian. Mendhak merupakan bentuk monomorfemis, yakni terdiri dari satu morfem dan termasuk ke dalam jenis morfem bebas yang memiliki makna. Dengan demikian, kata mendhak dapat berdiri sendiri karena telah memiliki makna leksikal dan tidak perlu bergabung dengan morfem lainnya.

Sewu dinane Dalam proses morfologi kata bilangan dalam bahasa jawa, bilangan yang memiliki empat digit, maka mendapat akhiran ewu.

Secara gramatikal, penamaan selametan masyarakat jawa banyak pada penggunaan bilangan yang mengalami afiksasi dan peleburan. Seperti neloni yang berasal dari bilangan telu yang mendapatkan peleburan menjadi nelu, dan mendapat akhiran $-i$ menjadi neloni. Begitu pula pada pitung dinane yang berasal dari bilangan pitu, kemudian mendapat akhiran -ng menjadi pitung. Penamaan yang diambil dari bilangan digunakan pada selametan yang dilakukan pada fase prakelahiran dan kematian. Sedangkan pada fase kehidupan, penamaan selametan yang banyak digunakan diambil dari tujuan kegiatan yang akan dilakukan dan diikuti dengan afiksasi maupun peleburan. Seperti pada brokohan yang berasal dari kata barokah, selametan tersebut bertujuan agar mendapat barokah. Kata tersebut mengalami peleburan dan akhiran -an menjadi brokohan. Begitu pula pada selametan itu sendiri yang berasal dari kata salamah, dan mendapat akhiran -an. Maka, proses gramatikal pada penamaan selametan masyarakat jawa selalu mengalami peleburan dan afiksasi dari kata dasar yang dipakai.

\section{Analisis Makna}

Selain mengalami proses gramatikal, penman selametan pada masyarakat jawa juga memiliki makna yang terkandung di dalamnya, sesuai dengan tujuan dan keinginan dari diadakannya selametan tersebut. 


\section{Tabel 3. Analisis Makna}

\begin{tabular}{|c|c|}
\hline Leksikon & Makna \\
\hline Neloni & $\begin{array}{l}\text { Lain dari makna leksikal, makna gramatikal baru ada kalau terjadi } \\
\text { proses gramatikal, seperti afiksasi, reduplikasi, komposisi, dan } \\
\text { kalimatisasi. Dalam jenis-jenis makna, kata neloni termasuk dalam } \\
\text { makna gramatikal. Karena kata neloni telah mengalami proses } \\
\text { gramatikal berupa afiksasi dan perubahan bunyi, namun tidak } \\
\text { mengubah maknannya. }\end{array}$ \\
\hline Mitoni & $\begin{array}{l}\text { Lain dari makna leksikal, makna gramatikal baru ada kalau terjadi } \\
\text { proses gramatikal, seperti afiksasi, reduplikasi, komposisi, dan } \\
\text { kalimatisasi. Dalam jenis-jenis makna, kata mitoni termasuk dalam } \\
\text { makna gramatikal. Karena kata mitoni telah mengalami proses } \\
\text { gramatikal berupa afiksasi dan perubahan bunyi, namun tidak } \\
\text { mengubah maknannya. }\end{array}$ \\
\hline Brokohan & $\begin{array}{l}\text { Makna leksikal dapat diartikan sebagai makna yang sesuai dengan } \\
\text { hasil yang sesuai dengan referennya, makna yang sesuai dengan } \\
\text { kehidupan kita.' Brokohan berasal dari kata barokah yang telah } \\
\text { mengalami proses gramatikal dalam bahasa jawa. Sehingga, proses } \\
\text { brokohan ini memiliki makna secara leksikal, yakni memohon } \\
\text { barokah atau berkah pada tuhan atas kelahiran sang bayi. }\end{array}$ \\
\hline Sepasaran & $\begin{array}{l}\text { Djajasudarma, menjelaskan makna referensial adalah makna yang } \\
\text { berhubungan langsung dengan kenyataan atau referent (acuan), } \\
\text { makna referensial disebut juga makna kognitif, karena memiliki } \\
\text { acuan. }^{10} \text { Makna ini memiliki hubungan dengan konsep, sama halnya } \\
\text { dengan makna kognitif. Makna referensial memiliki hubungan } \\
\text { dengan konsep tentang sesuatu yang telah disepakati bersama oleh } \\
\text { masyarakat pemakai bahasa. Sepasaran dalam masyarakat jawa } \\
\text { dianggap hal yang sakral. Sehingga, ketika seorang bayi tersebut } \\
\text { pertama kali lahir dalam hitungan pasar kalender jawa, maka perlu } \\
\text { diadakan selametan. Maka, sepasaran memiliki makna secara } \\
\text { referensial, atas dasar kepercayaan masyarakat jawa sendiri. }\end{array}$ \\
\hline Tedak siten & $\begin{array}{l}\text { Makna leksikal dapat diartikan sebagai makna yang sesuai dengan } \\
\text { hasil yang sesuai dengan referennya, makna yang sesuai dengan } \\
\text { kehidupan kita. }{ }^{11} \text { Tedak siten memiliki makna secara leksikal. } \\
\text { Karena sesuai dengan arti dari tedak siten sendiri, yaitu turun tanah. } \\
\text { Sehingga, ketika bayi tersebut pertama kali turun tanah, maka perlu } \\
\text { diadakan selametan. }\end{array}$ \\
\hline Selametan & Makna leksikal dapat diartikan sebagai makna yang sesuai dengan \\
\hline
\end{tabular}

\footnotetext{
${ }^{9}$ Abdul Chaer, Pengantar Semantik Bahasa Indonesia. (Jakarta: Rineka Cipta,2009), h. 60

${ }^{10}$ Fatimah Djaja Sudarma, Metode Linguistik Ancangan Metode Penelitian dan Kajian, (Bandung, PT. Eresco1993)

${ }^{11}$ Abdul Chaer, Pengantar Semantik Bahasa Indonesia. (Jakarta: Rineka Cipta, 2009), h. 60
} 


\begin{tabular}{ll}
\hline \multicolumn{1}{c}{ Leksikon } & \multicolumn{1}{c}{ Makna } \\
\hline $\begin{array}{l}\text { pernikahan } \\
\text { (untuk laki- }\end{array}$ & $\begin{array}{l}\text { hasil yang sesuai dengan referennya, makna yang sesuai dengan } \\
\text { kehidupan kita. }\end{array}$ \\
laki) & Selametan pernikahan memiliki makna secara \\
& memohon keselamatan atas pernikahan yang akan digelar. \\
Selametan & Makna leksikal dapat diartikan sebagai makna yang sesuai dengan \\
midodaren & hasil yang sesuai dengan referennya, makna yang sesuai dengan \\
& $\begin{array}{l}\text { kehidupan kita. }{ }^{13} \text { Selametan pernikahan memiliki makna secara } \\
\text { leksikal, yakni sesuai dengan makna dari selametan itu sendiri, yaitu }\end{array}$ \\
& memohon keselamatan atas pernikahan yang akan digelar. \\
& Midodaren yang memiliki arti seorang bidadari melambangkan \\
& seorang perempuan. Sehingga, selametan midodaren bermakna \\
& memohon keselamatan untuk calon pengantin perempuan.
\end{tabular}

\section{Nduduk pondasi}

Munggah molo Djajasudarma, menjelaskan makna referensial adalah makna yang berhubungan langsung dengan kenyataan atau referent (acuan), makna referensial disebut juga makna kognitif, karena memiliki acuan. ${ }^{15}$ Makna ini memiliki hubungan dengan konsep, sama halnya dengan makna kognitif. Makna referensial memiliki hubungan dengan konsep tentang sesuatu yang telah disepakati bersama oleh masyarakat pemakai bahasa.

Munggah molo memiliki arti menaikkan kuda-kuda rumah. Untuk menaikkan kuda-kuda, maka masyarakat jawa menggap perlu diadakan selametan untuk proses tersebut agar kuda-kuda tersebut kuat.

Telung dinane Makna leksikal dapat diartikan sebagai makna yang sesuai dengan hasil yang sesuai dengan referennya, makna yang sesuai dengan kehidupan kita. ${ }^{16}$ Peringatan tiga hari kematian atau telung dinane bertujuan untuk memperingati hari ketiga kematian seseorang.

\footnotetext{
${ }^{12}$ Abdul Chaer, Pengantar Semantik Bahasa Indonesia. Jakarta: Rineka Cipta, 2009), h. 60

${ }^{13}$ Ibid.

${ }^{14}$ Fatimah Djaja Sudarma, Metode Linguistik Ancangan Metode Penelitian dan Kajian, (Bandung: PT. Eresco, 1993)

${ }^{15}$ Fatimah Djaja Sudarma, Metode Linguistik Ancangan Metode Penelitian dan Kajian, (Bandung, PT. Eresco1993)

${ }^{16}$ Abdul Chaer, Pengantar Semantik Bahasa Indonesia. Jakarta: Rineka Cipta, 2009), h. 60
} 


\begin{tabular}{|c|c|}
\hline Leksikon & Makna \\
\hline & $\begin{array}{l}\text { Sehingga, kata telung dinane memiliki makna leksikal yang berarti } \\
\text { hari ketiga. }\end{array}$ \\
\hline Pitung dinane & $\begin{array}{l}\text { Makna leksikal dapat diartikan sebagai makna yang sesuai dengan } \\
\text { hasil yang sesuai dengan referennya, makna yang sesuai dengan } \\
\text { kehidupan kita. }{ }^{17} \text { Peringatan tujuh hari kematian atau pitung dinane } \\
\text { bertujuan untuk memperingati hari ke tujuh kematian seseorang. } \\
\text { Sehingga, kata pitung dinane memiliki makna leksikal yang berarti } \\
\text { hari ke tujuh. }\end{array}$ \\
\hline $\begin{array}{l}\text { Patang puluh } \\
\text { dinane }\end{array}$ & $\begin{array}{l}\text { Makna leksikal dapat diartikan sebagai makna yang sesuai dengan } \\
\text { hasil yang sesuai dengan referennya, makna yang sesuai dengan } \\
\text { kehidupan kita. }{ }^{18} \text { Peringatan empat puluh hari kematian atau patang } \\
\text { puluh dinane bertujuan untuk memperingati hari ke empat puluh } \\
\text { kematian seseorang. Sehingga, kata patang puluh memiliki makna } \\
\text { leksikal yang berarti hari ke empat puluh. }\end{array}$ \\
\hline satus dinane & $\begin{array}{l}\text { Makna leksikal dapat diartikan sebagai makna yang sesuai dengan } \\
\text { hasil yang sesuai dengan referennya, makna yang sesuai dengan } \\
\text { kehidupan kita. }{ }^{19} \text { Peringatan seratus hari kematian atau satusdinane } \\
\text { bertujuan untuk memperingati hari ke seratus kematian seseorang. } \\
\text { Sehingga, kata pitung dinane memiliki makna leksikal yang berarti } \\
\text { hari ke seratus. }\end{array}$ \\
\hline Mendhak & $\begin{array}{l}\text { Djajasudarma, menjelaskan makna referensial adalah makna yang } \\
\text { berhubungan langsung dengan kenyataan atau referent (acuan), } \\
\text { makna referensial disebut juga makna kognitif, karena memiliki } \\
\text { acuan. }^{20} \text { Makna ini memiliki hubungan dengan konsep, sama halnya } \\
\text { dengan makna kognitif. Makna referensial memiliki hubungan } \\
\text { dengan konsep tentang sesuatu yang telah disepakati bersama oleh } \\
\text { masyarakat pemakai bahasa. Mendhak merupakan kesepakatan } \\
\text { bahasa masyarakat jawa dalam menyebut satu tahun kematian } \\
\text { seorang manusia. }\end{array}$ \\
\hline Sewu dinane & $\begin{array}{l}\text { Makna leksikal dapat diartikan sebagai makna yang sesuai dengan } \\
\text { hasil yang sesuai dengan referennya, makna yang sesuai dengan } \\
\text { kehidupan kita. }{ }^{21} \text { Peringatan seribu hari kematian atau sewu dinane } \\
\text { bertujuan untuk memperingati hari ke seribu kematian seseorang. } \\
\text { Sehingga, kata sewu dinane memiliki makna leksikal yang berarti } \\
\text { hari ke seribu. }\end{array}$ \\
\hline
\end{tabular}

\footnotetext{
${ }^{17}$ Abdul Chaer, Pengantar Semantik Bahasa Indonesia...., h. 60.

${ }^{18}$ Abdul Chaer, Pengantar Semantik Bahasa Indonesia...., h. 60.

${ }^{19}$ Abdul Chaer, Pengantar Semantik Bahasa Indonesia...., h. 60.

${ }^{20}$ Fatimah Djaja Sudarma, Metode Linguistik Ancangan Metode Penelitian dan Kajian, (Bandung, PT. Eresco1993)

${ }^{21}$ Abdul Chaer, Pengantar Semantik Bahasa Indonesia. Jakarta: Rineka Cipta, 2009), h. 60
} 
Secara makna, penamaan selametan masyarakat jawa didominasi oleh makna leksikal dan makna gramatikal. Makna gramatikal merupakan makna yang didapatkan dari adanya proses gramatikal pada kata tersebut. Sedangkan makna leksikal dalam penamaan selametan masyarakat jawa ini merupakan makna yang melambangkan peristiwa yang dilakukan. Makna gramatikal terdapat pada penamaan selametan di tahap kehamilan dan kematian, seperti neloni, mitoni, patang puluh dino, dan nyewu. Sedangkan makna leksikal banyak didapatkan pada tahap kehidupan. Seperti brokohan, dan tedak siten. Adapula makna referensial yang didapatkan pada penamaan selametan masyarakat jawa, yakni pada tahap kehidupan dan kehamilan. Namun, makna referensial tidak banyak ditemukan seperti makna gramatikal dan leksikal. Maka, pada penamaan selametan masyarakat jawa makna yang didapatkan akibat adanya proses gramatikal yang diambil dari bilangan serta kegiatan atau tujuan yang dilakukan pada selametan tersebut.

\section{Penutup}

Berdasarkan data yang dianalisis, penamaan selametan masyarakat jawa memiliki variasi bentuk yang beragam. Dari bentuknya, penamaan selametan masyarakat jawa pada masa prakelahiran dan kematian banyak dibentuk dari kata bilangan yang mengalami proses gramatikal, sedangkan pada masa kehidupan penamaannya dibentuk dari tujuan atau kegiatan yang dilakukan dari selametan tersebut. Dari segi maknanya, penamaan selametan masyarakat jawa banyak memiliki makna secara leksikal. Penamaan tersebut sesuai dengan maksud dan tujuan dari diadakannya selametan. Seperti pada selametan nduduk pondasi yang memiliki makna menggali dasar bangunan. Nduduk pondasi merupakan proses pertama kali dalam membangun rumah, yakni membangun pondasi. Berbeda dengan bentuknya, secara makna penamaan selametan masyarakat jawa pada masa prakelahiran memiliki makna karena proses gramatikal. Sedangkan pada masa kehidupan dan kematian, memiliki makna secara leksikal dan referensial. Tujuan dari diadakannya selametan pada tahap tersebut karena pada keyakinan masyarakat jawa, fondasi merupakan dasar bangunan yang nantinya akan menopang rumah tersebut. Sehingga ketika membangun fondasi rumah, selametan diadakan bertujuan untuk memohon keselamatan dan keberkahan untuk rumah tersebut. Maka, pada penamaan selametan masyarakat jawa dibentuk dari bilangan dan kegiatan yang akan dilakukan. Pada setiap penamaan tersebut selalu memiliki berdasarkan tujuan dari diadakannya selametan. 


\section{Daftar Pustaka}

Bambang Hariyanto. 2017. Potret Keberagaman dan Kearifan Lokal di Gunung Kawi. Jurnal Uin-suka Vol. 18 no 2

Chaer, Abdul. 2002. Pengantar Semantik Bahasa Indonesia. Jakarta: Rineka Cipta.

Chaer, Abdul. 2007. Linguistik Umum. Jakarta: Rineka Cipta

Chaer, Abdul. 2009. Pengantar Semantik Bahasa Indonesia. Jakarta: Rineka Cipta

Djaja Sudarma, Fatimah, 1993. Metode Linguistik Ancangan Metode Penelitian dan Kajian. Bandung: PT.Eresco

Hendro Supatra. 2017. Pokok-pokok kebahasaaan dalam Kajian Antropologi Bahasa. Jurnal nusa Vol 12 no 2.

Imam Baehaqie. 2017. Nama-nama makanan dalam Sesaji Selametan Daur Hidup Masyarakat Jawa Studi Kasus di Kabupaten Wonogiri: Telaah Etnolingustik. http://etd.repository.ugm.ac.id.

Indah MR. 2016. Istilah-istilah Dalam Upacara Mitoni Pada Masyarakat Jawa di Desa Kalibiru Wetan, Keacamatan alibaru, Kabupaten Banyuwangi: Kajian Etnolinguistik. http://.repository.unej.ac.id

Lexy Moloeng, Metode Penelitian Kualitatif (Bandung: Remaja Rosdakarya), h. 4

Mahsun. 2005. Metodologi Penelitian Bahasa: Tahap Strategi, Metode dan Tekniknya. Jakarta: PT Raja Grafindo Persada

Mulyana. 2007. Morfologi Bahasa Jawa. Yogyakarta: Kanwa Publiser.

Nur Alfi Mu'anayah. 2016. Tradisi Suran Masyarakat Triaji:Sebuah Kajian Antropologi Linguistik. Jurnal Cita Ilmu Edisi 23 Vol xii.

Pateda, Mansoer. 2001. Semantik Leksikal. Jakarta : Rineka Cipta. 